\title{
TRIZ: The Enlightenment of the Training Mode of Excellent Chinese Engineers
}

\author{
Yiyang Fan, Yuting Qiu, Xing Zhang \\ Business School, University of Shanghai for Science and Technology, Shanghai, China \\ Email: fyyqq@usst.edu.cn, klee17@139.com, zstar_hr@sina.com
}

Received October 10, 2012; revised November 11, 2012; accepted November 22, 2012

\begin{abstract}
China has been the largest country in terms of the scale of higher engineering education in the world. The training plan of excellent engineers (TPEE) that launched in 2010 is to train various types of high-quality engineers and technical personnel who have strong innovative abilities and meet the need of economic and social development. The theory of inventive problem solving (TRIZ), as a scientific methodology to solve innovation problems, provides a theoretical basis and practical guideline for the training of excellent engineers. This paper analyzes the teaching philosophy and methods for the training of excellent engineers within TRIZ framework from the demand perspective, and then discusses the enlightenment of disseminating TRIZ in the following aspects, such as TRIZ application in science, technology, engineering, and mathematics (STEM) education, faculty development, platform development of innovative education and so on.
\end{abstract}

Keywords: TRIZ; Excellent Engineer; Training Mode; Engineering Education

\section{Introduction}

In order to implement the national medium and longterm educational reform and development plan and talent development program, Ministry of Education of PRC launched the training plan of excellent engineers (TPEE). The main objective is to train a large number and various types of high-quality engineers and technical personnel who have strong innovative abilities and meet the need of economic and social development.

The number of full-time postgraduates and doctoral candidates in Chinese colleges and universities is nearly 1.54 million at present. And the number of full-time undergraduates in school is over 22.31 million [1], among which more than one-third of students major in engineering [2]. China has been the largest country in terms of the scale of higher engineering education in the world. Since the founding of New China, especially since the reform and opening up, higher engineering education that has already trained tens of millions of engineering science and technology talents, strongly support the formation and development of China's industrial system, supports 30 years of rapid economic growth since China's reform and opening up, and makes important contributions to China's socialist modernization.

Nowadays science and technology is developing rapidly, the cycle of industrial upgrading and transformation is increasingly shortened and the frequency is increas- ingly accelerated. Redistribution of resources and Industrial regrouping which are caused by economic order changes under the economic globalization have proposed new requirements for the demand for engineering and technical personnel in the future. In this context, China needs diversified engineers [3] that the innovative and entrepreneurial engineers who target to creative and design, the implementation engineers who target to manufacture, and the service engineers who target to operation management. China's TPEE is the major reform of higher engineering education implemented in order to meet the above requirements.

\section{The Training of Excellent Engineers Requires Innovative Methods of TRIZ}

\subsection{The Origin of TRIZ}

The theory of inventive problem solving (TRIZ), developed by the Soviet inventor Geinrich Alshuller, is treasured as national "Golden Touch" of the Soviet Union. It derived from the study of 2.5 million high-level inventions in the global patent literature after the 20th century. Following the end of the cold war in 1990s, TRIZ was brought overseas and began to popularize in Europe and the US. Nowadays, it has been widely recognized as an authoritative and effective problem-solving method and basic theory of computer-aided innovation. 


\subsection{Application of TRIZ to Innovative Education}

TRIZ methodology consists of a generic spectrum of solutions for innovation, procedures and tools for technical inventions such as eight patterns of evolution, 39 parameters of the contradiction table (Matrix) and 40 principles of invention. It is feasibly applied in technical industries such as machinery, electronics, biology, chemistry and military engineering, and then extended to a broader application in non-technical areas such as management, marketing, education and psychology. TRIZ, as an innovative methods and philosophy, is the key to innovative education. Many countries have introduced TRIZ into the curriculum and encouraged teachers to innovate teaching methods, inspire students' inventive thinking and develop students' creativity.

Czech and Britain mechanical engineering designers broke out of existing heat exchanger conceptual paradigms by using TRIZ's Ideal Final Result (IFR) method, and optimized key functional relationships to produce a novel design solution. This TRIZ work was easy to operate and teach. According to the case study, B. Busov [4] regarded TRIZ as a good mode in engineering education and innovative education in 21th century.

Within the University of Twente, the Netherlands, TRIZ was presented as an 84 or 140 hours master course. Wessel W. Wits [5] found that students showed a lot of interest and was capable of finding inventive solutions for both small parts and big project design throughout the course.

Students in Pennsylvania State University increased their creative output by using TRIZ methods to design ice dispenser. M. Ogot and G.E. Okudan [6] recommended TRIZ as a systematic creativity methods and innovative learning styles in engineering education.

Toru Nakagawa [7] in Osaka Gakuin University launched a Six-Box Scheme of TRIZ training seminars for graduate students. The study showed that TRIZ methodology encouraged students' structured inventive thinking to derive creative engineering works.

In 2009, Ministry of Science and Technology in China carried out TRIZ theory training nationwide. TRIZ methodology has applied in engineering education as a new way to explore innovative higher engineering education, to develop students' creativity and train excellent engineers in the future. Changzhou engineering vocational and technical college [8] ran TRIZ courses and originality competition to push through education reform and promote students' creativity. Tsinghua University, Sichuan University and Southwest Jiaotong University [9] have placed TRIZ on the curriculum for the graduate students to improve their creativity and innovative abilities. According to the overseas experiences of introducing TRIZ into curriculum, implementing TRIZ method- ology in China's higher engineering education is an effective way to develop students' creativity and innovative abilities.

\subsection{The Training of Excellent Engineers Needs Innovative Education of TRIZ}

In the era of information and technology explosion, industries accelerate upgrading and transformation, modern engineering trends towards systematization, intelligence and humanity, technological innovation leads to inter-industrial diffusion of knowledge and technology, and consumers need better products and services. In order to construct an innovative country, support industrial development, enhance the comprehensive national strength, and respond to the challenges of economic globalization, China need urgently to train a large number of innovative engineering talents and excellent teams of engineers.

What is the standard of excellent engineers? This seems to be very difficult to define. Only the employers have the most power to define whether he (or she) is outstanding. And what is the definition of innovative ability? Some explicit index of innovative ability is very easy to distinguish and define, for example, a person holds the patent on an invention or designs some new products. But implicit standards of innovative competency are difficult to define. Universities train talents for the future. Whether he (she) has innovative capability, or the possibility to become a good engineer, depends on such things as: the ability to think independently and solve problems based on basic professional techniques and skills, to solve the ever new technical problems, to solve the non-own professional technical problems, a healthy mind, a spirit to cooperate with others and so on. All in all, people with a certain learning ability and innovative ability can become a good engineer.

The university's main task is to impart knowledge and skills which are always not able to meet the requirements for the job. The person only with self-learning ability and ingenuity can adapt to the changing work environment, qualify for the job requirements, and achieve high performance. Therefore, it is a more important and difficult task to improve students' inventive thinking and creative abilities than imparting knowledge and skills.

TRIZ, as an effective guidance tool, extrapolates from the particular to the general and further refines a series of scientific methods and rules of invention and technical problem solving on the analysis of a number of highlevel invention patents. TRIZ, which consists of many solutions for the technical problems of invention and innovation, is easy to integrate with professional courses and operate on teaching methods to inspire inventive thinking and problem-solving abilities of students. Accordingly, it is very meaningful to apply TRIZ to the training mode of excellent engineers. 


\section{Training Mode of Excellent Engineers within TRIZ Framework}

Currently China's higher engineering education face serious problems [2] that a huge mismatch between supply and demand, the convergence of training objectives and mode, the absence of pragmatic teaching contents, the maladaptive teaching system for the characteristics of engineering, and the lack of initiative on the part of students. Introducing TRIZ into higher engineering education is worthy of reference and enlightenment in both innovating management model and philosophy in higher engineering education and reforming curriculum system.

\subsection{TRIZ Inspires New Teaching Philosophy and Methods for Educators}

The innovative way of thinking and solutions for inventions and problems within TRIZ framework, show strong logicality for knowledge cognition and feasibility of innovative approaches and provide useful guideline on innovation and entrepreneurship education. TRIZ is a summary of inventions and innovative practice and there are many choices of teaching methods to develop students' inventive thinking and creative abilities within the TRIZ framework.

As shown in Table 1, TRIZ system develops many

Table 1. TRIZ guide to innovative teaching methods.

\begin{tabular}{|c|c|c|c|c|}
\hline \multicolumn{2}{|c|}{ TRIZ innovative methods } & \multirow{2}{*}{\begin{tabular}{l}
\multicolumn{1}{c}{ Teaching purpose } \\
Systematic thinking, time-space \\
associative thinking and creative \\
thinking training
\end{tabular}} & \multirow{2}{*}{$\begin{array}{l}\text { Teaching target } \\
\text { Any knowledge structure, } \\
\text { knowledge level and } \\
\text { professional background }\end{array}$} & $\begin{array}{l}\text { The suggestion of } \\
\text { teaching methods }\end{array}$ \\
\hline \multirow{5}{*}{ 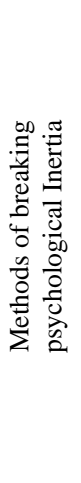 } & Nine-Screen Method & & & $\begin{array}{l}\text { Activate students' thinking in } \\
\text { classroom, and assign various } \\
\text { group work }\end{array}$ \\
\hline & $\begin{array}{l}\text { STC(Size-Time-Cost)/ } \\
\text { RTC (Rsource-Time- } \\
\text { Cost) Operator }\end{array}$ & $\begin{array}{l}\text { Analyze the principal contradiction and } \\
\text { focus on problem solving by } \\
\text { three- dimensional thinking }\end{array}$ & $\begin{array}{l}\text { Students with the clear research } \\
\text { purpose }\end{array}$ & $\begin{array}{l}\text { Conduct course design, and } \\
\text { analysis of engineering, economic, } \\
\text { and social issues }\end{array}$ \\
\hline & $\begin{array}{l}\text { Smart Little People } \\
\text { Method }\end{array}$ & $\begin{array}{l}\text { Seek the functions to be improved and } \\
\text { perfect the design of system } \\
\text { architecture }\end{array}$ & $\begin{array}{l}\text { Specialized courses for students } \\
\text { major in Mechanical } \\
\text { engineering }\end{array}$ & $\begin{array}{l}\text { Encourage systems, parts, structural } \\
\text { design and innovation }\end{array}$ \\
\hline & $\begin{array}{l}\text { Fantasy scenes } \\
\text { analysis method }\end{array}$ & $\begin{array}{l}\text { Seek solutions to the problem with } \\
\text { different new ideas or imagination } \\
\text { iteratively }\end{array}$ & $\begin{array}{l}\text { Any knowledge structure, } \\
\text { knowledge level and } \\
\text { professional background }\end{array}$ & $\begin{array}{l}\text { Activate students' thinking in } \\
\text { classroom, and assign various } \\
\text { group work }\end{array}$ \\
\hline & $\begin{array}{l}\text { IFR (Ideal Final } \\
\text { Result) }\end{array}$ & $\begin{array}{l}\text { Seek to eliminate the deficiencies of the } \\
\text { original system, and maximize } \\
\text { favorable factors to attain ideal results }\end{array}$ & $\begin{array}{l}\text { Students with the clear research } \\
\text { purpose }\end{array}$ & $\begin{array}{l}\text { Conduct analysis of engineering, } \\
\text { economic, and social issues }\end{array}$ \\
\hline \multirow{5}{*}{ 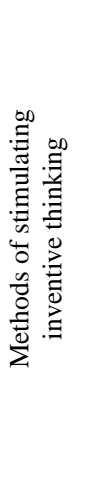 } & $\begin{array}{l}\text { Trial and error } \\
\text { method }\end{array}$ & $\begin{array}{l}\text { Repeated attempts to find solutions to } \\
\text { the problem, and divergent thinking } \\
\text { training }\end{array}$ & $\begin{array}{l}\text { Any knowledge structure, } \\
\text { knowledge level and } \\
\text { professional background }\end{array}$ & $\begin{array}{l}\text { Activate students' thinking in } \\
\text { classroom, and assign various } \\
\text { group work }\end{array}$ \\
\hline & Brainstorming & $\begin{array}{l}\text { Free-thinking and intellectual } \\
\text { stimulation to spark new ideas and train } \\
\text { creative thinking }\end{array}$ & $\begin{array}{l}\text { Any knowledge structure, } \\
\text { knowledge level and } \\
\text { professional background }\end{array}$ & $\begin{array}{l}\text { Activate students' thinking and } \\
\text { discussion in classroom, and assign } \\
\text { various group work }\end{array}$ \\
\hline & $\begin{array}{l}\text { Morphological } \\
\text { analysis }\end{array}$ & $\begin{array}{l}\text { Observe systematically and select the } \\
\text { best combinations }\end{array}$ & $\begin{array}{l}\text { Juniors with professional } \\
\text { knowledge, who majored in } \\
\text { STEM or economics }\end{array}$ & $\begin{array}{l}\text { Conduct special researches and } \\
\text { new product development }\end{array}$ \\
\hline & $\begin{array}{l}\text { LT } \\
\text { (Lateral Thinking) }\end{array}$ & $\begin{array}{l}\text { Similar to brainstorming, view the } \\
\text { same thing from different perspectives } \\
\text { to train divergent thinking }\end{array}$ & $\begin{array}{l}\text { Any knowledge structure, } \\
\text { knowledge level and } \\
\text { professional background }\end{array}$ & $\begin{array}{l}\text { Activate students' thinking and } \\
\text { discussion in classroom, and assign } \\
\text { various group work }\end{array}$ \\
\hline & Checklist method & $\begin{array}{l}\text { Conceive creatively through different } \\
\text { angles by checklist methods to train } \\
\text { solution-focused thinking }\end{array}$ & $\begin{array}{l}\text { Students with the clear research } \\
\text { purpose and professional } \\
\text { background }\end{array}$ & $\begin{array}{l}\text { Encourage invention and creative } \\
\text { activities }\end{array}$ \\
\hline \multirow{4}{*}{ 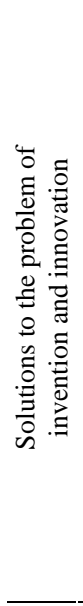 } & $\begin{array}{l}\text { Contradiction } \\
\text { matrix separation } \\
\text { principles and its } \\
\text { application }\end{array}$ & $\begin{array}{l}\text { Analyze the impact of contradictions } \\
\text { attributes on the technology systems } \\
\text { and find a solution to the problem } \\
\text { based on the separation principle of } \\
\text { space, time, conditions, and } \\
\text { system-levels }\end{array}$ & $\begin{array}{l}\text { Students with the clear research } \\
\text { purpose and professional } \\
\text { background }\end{array}$ & $\begin{array}{l}\text { Encourage invention and creative } \\
\text { activities, and conduct various } \\
\text { researches of engineering, } \\
\text { economics and social management }\end{array}$ \\
\hline & $\begin{array}{l}\text { Identification and } \\
\text { separation between } \\
\text { physical and technical } \\
\text { contradiction }\end{array}$ & $\begin{array}{l}\text { Identify the impact of changing system } \\
\text { parameters and train the ability to } \\
\text { analyze and solve problems }\end{array}$ & $\begin{array}{l}\text { Students with the clear research } \\
\text { purpose and professional } \\
\text { background }\end{array}$ & $\begin{array}{l}\text { Encourage invention and creative } \\
\text { activities, and conduct various } \\
\text { researches of engineering, } \\
\text { economics and social management }\end{array}$ \\
\hline & $\begin{array}{l}\text { Substance-field } \\
\text { analysis }\end{array}$ & $\begin{array}{l}\text { Analyze the changes of various factors } \\
\text { affecting the system from the point of } \\
\text { view of substance-field analysis, } \\
\text { optimize the system architecture and } \\
\text { seek solutions to the problem }\end{array}$ & $\begin{array}{l}\text { Students with the clear research } \\
\text { purpose and professional } \\
\text { background }\end{array}$ & $\begin{array}{l}\text { Conduct various special researches } \\
\text { of engineering, project, economics } \\
\text { and social management }\end{array}$ \\
\hline & $\begin{array}{l}\text { Identification of } 39 \\
\text { generic engineering } \\
\text { parameters }\end{array}$ & $\begin{array}{l}\text { Refine engineering parameters in } \\
\text { specific issues, and seek tools for } \\
\text { problem solving }\end{array}$ & $\begin{array}{l}\text { Students with professional } \\
\text { knowledge }\end{array}$ & $\begin{array}{l}\text { Encourage invention and creative } \\
\text { activities, and conduct various } \\
\text { special researches of engineering, } \\
\text { economics and social management }\end{array}$ \\
\hline
\end{tabular}


types of methods for breaking psychological inertia and stimulating inventive thinking, and some of them are familiar to people, such as brainstorming. Teachers can use these methods in many teaching aspects, which are applicable to the general population and not restricted by their background knowledge. Some innovative ways of thinking, such as morphological analysis and checklist method, are more suitable for the professionals. TRIZ's solutions to the problem of invention and innovation, for example, 39 general engineering parameter matrix and 40 inventive principles can be ideally used for instructing students in inventions, innovation activities, and in various monographic studies.

\subsection{Apply TRIZ to STEM Education for Thinking Training and Practices}

The essence of TRIZ is seeking for solutions to the innovation problems by innovative way of thinking and specialized methodology. In 2009, Ministry of Science and Technology of PRC began to introduce TRIZ to training, and the aim is to improve the innovative capability of China's scientific and technical personnel. The experiences of TRIZ practices in foreign universities and industrial applications indicated that TRIZ has played a catalytic role in shortening the development cycle of new products and original $R \& D$ and in improving the efficiency of innovation.

STEM education, as a cradle of future engineers, is necessary to integrate with TRIZ in terms of the general education or professional education. The TRIZ practices in graduation design of hydraulics in Heilongjiang institute of science and technology [10] indicated that the number of design proposals increased $25 \%$, and the effective high-level scheme accounted for $12 \%$, which improved the quality of graduation design [10].

Almost all the STEM courses in Chinese universities contain 39 general engineering parameters and 40 invention principles. Therefore, launching TRIZ education early can train more excellent engineers and innovative talent for China's industrial development. Currently in China's higher education, STEM occupy more than half the proportion of a wide variety of scientific specialties, most STEM colleges offer electronic engineering, mechanical engineering, engineering thermal physics and materials engineering. The process of training excellent engineers is shown in Figure 1. Acquiring fundamental and professional knowledge and applying theory to practice can equip the students with the excellent quality of engineers. The education of excellent engineers can be proved successful when a graduated STEM student has invention patents, great innovative achievements, high-quality thesis or problem-solving abilities and so on.

The TRIZ methodology is most likely to be accepted by STEM students. Figures $\mathbf{1}$ and $\mathbf{2}$ look very similar.
The former process is to improve the excellent quality and ingenuity of engineers by learning, accumulation of knowledge, and practical skills. The latter one is to utilize the fundamental knowledge of operation and professional knowledge to identify problems, and then use specialized techniques and tools to solve the problem directly and attain innovative and creative achievement. Therefore, promoting the TRIZ application in STEM education is an effective way of carrying out the training plan of excellent engineers.

\subsection{Enhance Faculty Development for Innovative Education of TRIZ}

University faculties’ innovative capability and philosophy determine the effect of innovative education. But many of STEM teachers in China's universities don't understand the innovative theory of TRIZ, and could hardly integrate it with professional courses. Accordingly universities should attach importance to carrying out researches and training classes of TRIZ, and encourage teachers to participate in TRIZ practice, interdisciplinary research activities and industrial technological innovation through the innovative platform of TRIZ and universityindustry research cooperation.

First of all, extend application of TRIZ among STEM teachers and integrate innovative methods and philosophy

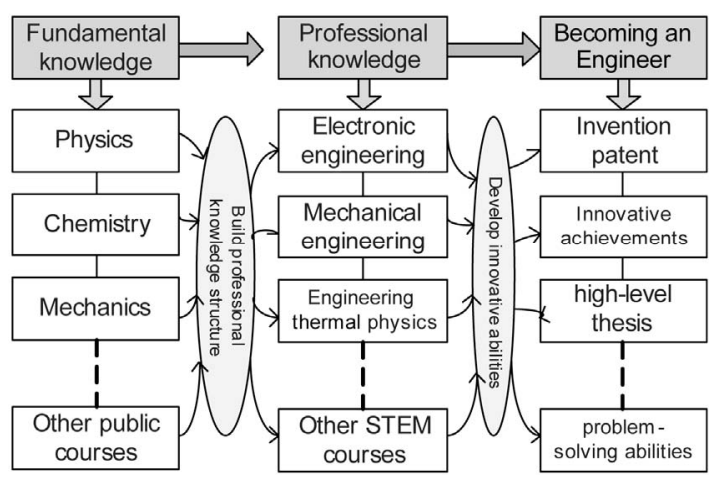

Figure 1. The process of training excellent engineers.

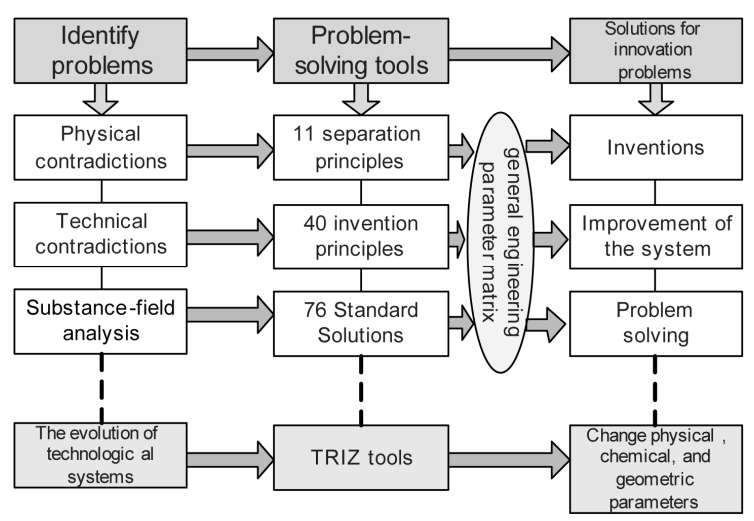

Figure 2. The innovative problem-solving process of TRIZ. 
of TRIZ with professional education. Then, build a TRIZ education team with multidisciplinary teachers which mainly consist of STEM teachers and partly seek the support of enterprises' TRIZ tutors.

\subsection{Develop a Cooperative and Resource-Sharing Platform for TRIZ Education}

TRIZ originated in the exploration of industrial innovation and technical inventions in engineering fields. Since 2009, the Chinese government, enterprises, universities and research institutions have embarked on promoting the application of TRIZ, but that is not enough to meet the great demand of China's higher engineering education. The main reason is the lack of training facilities for the technological innovation, teachers with innovative spirit and feasible teaching methods.

The principle of China's training plan of excellent engineers is to provide guidance for industry, enhance cooperation between universities and enterprises, implement systematically, and diversify in forms. Developing a cooperative and resource-sharing platform for TRIZ education, is not only to provide a continuing education platform to improve the $R \& D$ capabilities of scientific and technical personnel in enterprises, but also to offer the innovative education and training opportunities which closely integrated with enterprises for teachers and students in universities.

As shown in Figure 3, the government, enterprises, universities and research institutions establish the TRIZ education platform together. This TRIZ platform provides many types of educational resources, including the theory study, academic exchanges, public courses, methodological training for engineering innovation, case study and innovation contests. And the platform also offers public resources, such as dissemination of TRIZ, professional training, open courses and innovation competitions, for enterprises, research institutions, technology service firms

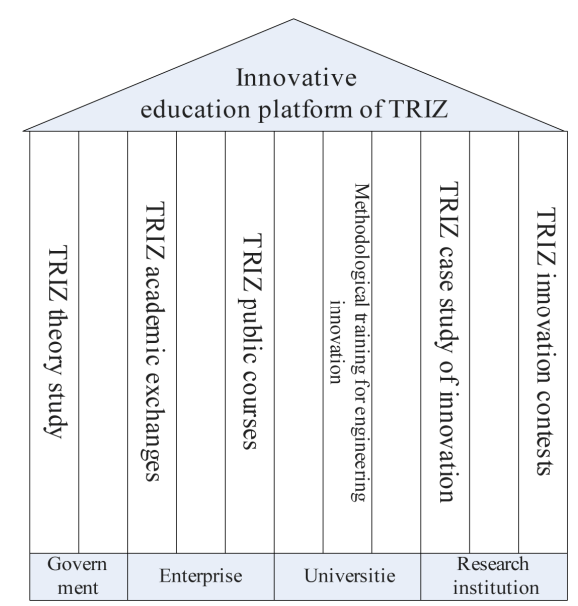

Figure 3. Innovative education platform of TRIZ. and universities.

\section{Conclusions}

The practice of applying TRIZ to higher engineering education indicates that TRIZ methodology significantly improves the engineering and innovative abilities of students.

Because of the scientific, pragmatic, and operable attributes, TRIZ can be an effective way to develop the innovative abilities, professional competence, and engineering capabilities of students, and also a great starting point for the implementation of China's TPEE.

At present, China has 194 colleges and universities launching the TPEE as pilot study of teaching reform. And the practices that integrate TRIZ with the teaching form of excellent engineers training afford valuable lessons for the college and university educators.

From the perspective of teaching reform, there are some recommendations for the application of TRIZ:

- Go out of colleges and universities, and cooperate with the industry. Learn from the enterprises which implement TRIZ currently, participate in their R\&D and new product development activities, and employ corporate engineers to guide the TRIZ teaching reform.

- Carry out the TRIZ teaching reform step by step. Develop different forms of TRIZ courses for different levels of students, such as junior college, undergraduate, graduate and doctoral students, and different depths for different subjects.

- Give full play to the role of professional teachers. The STEM courses consist of the engineering parameters of TRIZ, and the STEM teachers are the front-line communicators and initiators.

- Carry out TRIZ education combined with one's own characteristics of TPEE. According to schools' traditional expertise, location, educational resources, explore the compatible teaching mode of TRIZ.

- Develop a standard teaching and training system for TRIZ. TRIZ has its own logic and regularity. Thus developing a standard training system, such as the training platform and software, can greatly improve the efficiency of the dissemination of knowledge and the effectiveness of teaching.

\section{Acknowledgements}

This research was financially supported by the NSFC under Grant Nos. 71171134/G012, China Shanghai Municipal Research Project of Education and Science 2011 (B11041).

\section{REFERENCES}

[1] Ministry of Education of China, "Statistical Report of National Education Development Affairs,” 2011. 
http://www.moe.edu.cn/publicfiles/business/htmlfiles/mo e/moe_633/201208/141305.html

[2] G. F. Zhu, "Current Status and Prospects of Engineering Education in China," Research in Higher Education of Engineering, Vol. 22, No. 6, 2011, pp. 1-4.

[3] P. G. Li, X. D. Xu and G.S. Chen, “On Practical Teaching of Undergraduate Engineering Education in China: Problems and Causes," Research in Higher Education of Engineering, Vol. 23, No. 3, 2012, pp. 1-6.

[4] B. Busov, D. L. Mann and P. Jirman, "TRIZ and Invention Machine: Methods and Systems For Creative Engineering and Education in the 21st Century," 1st International Conference on Advanced Engineering Design, Prague, May 1999, pp. 1-10.

[5] W. W. Wits, T. H. J. Vaneker and V. Souchkov, "Full Immersion TRIZ in Education," Proceedings of the TRIZ Future Conference 2010, Bergamo, 3-5 November 2010, pp. 269-276.

[6] M. Ogot and G. E. Okudan, "Systematic Creativity Methods in Engineering Education: A Learning Styles Per- spective,” International Journal of Engineering, Vol. 22, No. 3, 2006, pp. 566-576.

doi:10.1080/03043790600797335

[7] T. Nakagawa, "Education and Training of Creative Problem Solving Thinking with TRIZ/USIT,” Procedia Engineering, Vol. 9, 2011, pp. 582-595. doi:10.1016/j.proeng.2011.03.144

[8] D.-Z. Xu and W. Xiong, "Research and Exploration of Introducing TRIZ into Innovation Education of Institutions of Higher Vocational Education,” Journal of Shenyang Institute of Engineering (Social Sciences), Vol. 6, No. 1, 2010, pp. 93-99.

[9] X. F. Zhang, "TRIZ Tactics into Classroom Teaching," Journal of Tianjin Normal University (Elementary Education Edition), Vol. 12, No. 2, 2011, pp. 32-35.

[10] X. T. Liu, C.-Y. Zhao and P. Xu, "TRIZ Theory and Students' Innovative Ability Cultivation,” Higher Education Forum, Vol. 6, No. 3, 2010, pp. 29-31. 